Journal

of Geography

Politics and Society

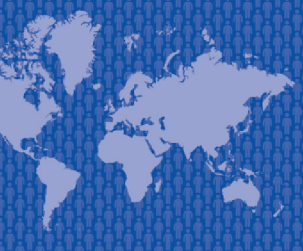

$8(2) / 2018$

\section{Journal of Geography, Politics and Society}

$2018,8(2), 54-65$

DOI 10.4467/24512249JG.18.015.8221

\title{
SELF-PROCLAIMED REPUBLICS OF EASTERN UKRAINE - CORRIDOR OF DEVELOPMENT TRAJECTORIES (POLITICAL, ETHNO-DEMOGRAPHIC AND SOCIO-ECONOMIC ASPECTS)
}

\author{
Sergey Sushchiy (1), Taras Medvedkin (2) (3) \\ (1) Institute of Social, Economic and Humanitarian Research, Southern Scientific Center, Russian Academy of Sciences, Chekhov 41, 344006 Rostov-on-Don, \\ Russia, \\ e-mail: SS7707@mail.ru (corresponding author part 1-2,4) \\ (2) Institute of Social, Economic and Humanitarian Research, Southern Scientific Center, Russian Academy of Sciences, Chekhov 41, 344006 Rostov-on-Don, \\ Russia, \\ e-mail: taras.medvedkin@gmail.com (corresponding author part 3-4) \\ (3) World Economy, Politics and Globalization Department, Rostov State University of Economics, Sadovaya 69, 344002 Rostov-on-Don, Russia,
}

\section{Citation}

Sushchiy S., Medvedkin T., 2018, Self-proclaimed republics of Eastern Ukraine - corridor of development trajectories (political, ethno-demographic and socio-economic aspects), Journal of Geography, Politics and Society, 8(2), 54-65.

\section{Abstract}

This article examines the political, ethno-demographic and socio-economic aspects of the self-proclaimed republics of Eastern Donbass. It is concluded that the most likely scenario is to preserve them as politically independent from Kiev, the pro- Russian societies with an uncertain international political status.

The process of state bodies' system formation in Eastern Donbass (Donetsk and Lugansk people's Republic - D(L)PR), further legitimizing of the vertical power of the republics through activation of local party life and finalizing the system of elections for leaders and deputy corps of various levels are expected to be completed in the coming years.

The socio-political fate of Donbass will also largely determine the further ethnic evolution of its population, both in the western (Ukrainian) and the eastern ("republican") parts. The consolidation of the republics as stable political and administrative and territorial entities in the medium term (by 2025-2030) may lead to a quantitative predominance of the Russian population within their borders (taking into account bi-ethnophors with Russian ethnic self-identification).

At present the only realistic scenario of socio-economic development of the republics remains their progressive "shadow" integration into the life cycles of the Russian economy. In the next few years a serious spatial transformation of the entire infrastructure complex of the $\mathrm{D}(\mathrm{L}) \mathrm{PR}$, including a network of transport communications and the basic systems of social life support, is expected. The transformation is caused by a radical turn of trade and economic ties of the region to Russia and the need to move the central infrastructural hubs of the republics away from the front line.

\section{Key words}

the self-proclaimed Republic, Eastern Donbass, the socio-political dynamics, ethnic and demographic prospects, economic potential 


\section{Socio-political dynamics of Eastern Donbass}

The process of institutionalization of new societies in different aspects of their activity was quite uneven in its pace. In summer 2014, a "force" component of the republics had been undergoing its formation at a higher rate. In the context of a violent escalation of an armed confrontation in Eastern Ukraine insurgents' military inconsistency would merely cancel the project of new pro-Russian communities. As a result, during the first six months of the foundation the landmark of people's republics, hardly their only social fact, was a militia which went from disparate, poorly armed groups to a large semi-professional army (Сущий, 2015).

The rest of the spheres of the social life of Donbass regions controlled by the militia continued to keep their established forms. Local industries used to function as a part of the economic system of Ukraine. Financial flows were still directed to Kiev. The administrative and managerial apparatus also remained the same. Left "in limbo", the major massive of officials took a wait-and-see approach, trying to keep their position in the management line of Ukraine if possible and avoiding an open conflict with militia leaders at the same time.

Since summer 2014 a socio-political and administrative and managerial formation of the selfproclaimed republics is accelerated. In the next two years a system of state bodies is established, which allows claiming on socio-political legitimacy and managerial stability of new state entities.

Nevertheless, their political future was under the question almost all this time, as the Minsk negotiating process launched in September 2014 envisaged, at least in writing, a certain road map for returning the republics to the full political and administrative control of Kiev. Another issue is that each party interpreted this way individually, what initially facilitated the impasse over the negotiating process.

There had been a recurrent opinion in expert literature in 2015-2016 that Moscow being seriously interested in Eastern Donbass itself keeps this region as a bargaining chip in a big geostrategic game a "commodity" for an international political bargaining with its global opponents, first of all, with the USA (Украинский кризис..., 2015; Матишов, 2016). And as soon as corresponding mutual concessions are negotiated (for example, on Syria or on the sanctions list), the Kremlin will cede power over the selfproclaimed republics to the Ukrainian authorities.

This point of view came from an assumption on the entirely artificial genesis of the $D(L) P R$ being the Kremlin's project per se, which obviously contradicted the reality. If Moscow had really started targeted construction of Novorossiya, the spatial format of pro-Russian societies of Eastern Ukraine would have included at least all territory of Donbass, but probably considerably gone beyond its borders.

However, it is impossible to deny the most significant assistance provided to the insurgent movement in Donbass since its emergence from powerful groups of the Russian political, administrative and military elite and nationally-oriented groups of Russian society.

Another point is no less substantial - after everything what happened in the East of Ukraine in 2014-2015, even if the Russian authorities made decisions on the future of Eastern Donbass, they would already fail to "return" the rebelled region of the Ukrainian authorities in their contemporary militant anti-Russian format without the most serious reputational losses in their own Russian society. Even a propaganda machine of central Russian TVchannels working at full power would not be able to justify such a step. It is explained by the fact that such gear would automatically presuppose an extremely rigid "clean-up" operation of all pro-Russian elements of two republics, which a large patriotically-oriented part of the Russian society would not forgive the higher authorities of the country. Finally, there was an influential class of the D(L)PR supporters among representatives of the Russian elite (in its political, administrative and managerial and "force" segments). Thus, "ceding" the republics to Ukraine would, in fact, trigger a serious split in the ruling class of Russia.

But what was said does not mean that initially Moscow deliberately torpedoed the Minsk process. The motives of the Russian authorities appear to have been entirely transparent. Russia was ready to facilitate returning the separatist region to Ukraine, but only in case of recognition of all socio-legal and socio-cultural peculiarities of Eastern Donbass by Ukraine. In fact, Moscow proposed Kiev to make the same with the self-proclaimed republics what it made a decade ago with the Chechen Republic - to give the separatist region a high level of autonomy (Сущий, 2015; Матишов, 2016). To change methods of rigid unification to the system of measures of financial and economic and socio-cultural stimulation of integration processes - comprehensive activities planned for realization for decades.

So in Moscow's opinion, the political return of rebelled Donbass to Ukraine could happen only on condition that Kiev refused to make forced "ukrainization" of the region, agreed to give it its famous administrative and managerial and socio-cultural autonomy including saving multiple elements of "Russian identity" and Russian centricity which 
were intrinsic to the life of the local population and its social practices (Проблемы полиэтничного макрорегиона..., 2015; Украинский кризис..., 2015).

The acceptance of such variant of returning control over separatist territories in fact by Kiev and all the political class of the country would mean (and presupposed) dismantling of the supporting construction of contemporary Ukraine as a unitary state. Apart from this, delegating special administrative duties and socio-cultural opportunities to Eastern Donbass, refusal of complex lustration of professional communities and strict persecution of all proRussian "collaborators" presupposed a cardinal value transformation of the anti-Russian strategic course of Kiev, a deep revision of the state socio-cultural program which the current authorities of Ukraine and its extremely active nationalist avant-garde could not undergo under any circumstances (Пихорович, 2015; Матишов, 2016). Taking into account how firmly this avant-garde controls the power and holds the central positions in the Ukrainian society, it is obvious that this scenario was absolutely unrealizable from the first steps of the negotiation process.

Thus, Russia was ready to "trade" with Eastern Donbass. But only with Ukraine itself and not with the USA or the European Union. However, initially the "price" offered by the parties in this diplomatic bargaining differed most significantly. Any negotiation is a search for a mutually satisfactory compromise (a "favorable price"). But even taking into account the maximum concessions each of the parties could admit, a common space for a dialogue/a compromise did not arise. In essence, it was already evident from the first steps of the negotiation process (that is, since autumn 2014). However, better realizing the impossibility of a "deal", the parties could not refuse to participate in negotiations for a number of reasons and therefore quickly enough turned them into a formal procedure well-recognized by all participants, a diplomatic ritual.

In such situation the maintenance of the existing status quo was the most likely - Eastern Donbass was to remain in the intermediate socio-political status for an indefinitely long time, that is to remain as a potential "commodity". Since only the return of the republics to Ukraine or their annexation to the Russian Federation or, finally, their recognition by Russia as independent states would mean their loss of commodity objectivity and their transformation either into an internal element of the Ukrainian (or Russian) state or into an independent (even formally) subject of international political life. However, none of these options could be considered real. And the uncertainty persisted.
Meanwhile, the "frozen" status did not mean absolute socio-political static of Eastern Donbass. While the parties of the negotiation process were bickering with no result, two republics with their population of almost three million people lived their lives testing new forms of social organization and economic survival, gradually adapting to the conditions of long-term system uncertainty. And the pro-Russian focus of this new life led it further from the rest of Ukraine, therefore increasing its potential transaction costs on potential reintegration of Eastern Donbass in its cycles.

As a result the initially phantom probability of a positive compromise approximately failed completely by mid - the end of 2016. And although the negotiation process continued to take its course, the understanding that the point of no return by the self-proclaimed republics had passed activated the Ukrainian nationalists who decided to stop the diplomatic games that had become absolutely meaningless from their point of view. The trade and economic blockade of Eastern Donbass they organized and which is supported by the official Kiev, accelerated the process of socio-political and economic self-determination of the republics. The subsequent recognition of passports of the people's Republic by Russia was another step on their way to their own, unrecognized but stable statehood.

A comparison of the self-proclaimed republics with Transnistria is spread in the expert community (Рожин, 2014). Meanwhile, there is much more typological similarity of Eastern Donbass with NagornoKarabakh. Of course, a comparative analysis of all the unrecognized post-Soviet states reveals much in common. But, recalling the dynamics of the Armenian-Azerbaijani confrontation, we find that the situation in the east of Ukraine repeats the same conflict track in its main trends.

Let us recall that Armenia having not officially recognized the independence of the Nagorno-Karabakh Republic (NKR) during the escalation of the armed confrontation between the NKR and Azerbaijan provided various kinds of assistance to the insurgents, which, however, was of a "private" nature - Armenia did not enter the open war with the neighboring state. Correspondingly, the units of the Armenian army were not officially on the line of confrontation either. But it did not prevent the development of a broad voluntary movement in Armenia resulting in the reinforcement of insurgent groups (including the military personnel). And according to its size and qualitative characteristics, the formed militia appeared to resist the professional army of Azerbaijan, its demographic and economic potential 
of being 50-100 times greater than the NKR's capacity (Корнел, 2000).

In spring 1994, after a period of active hostilities which exhausted both opponents, the parties of the conflict reach the "clinch" stage. In other words, they are on the line of an approximate territorial balance which minimizes the possible mobility of the front in one direction or another. On 12 May, 1994 a ceasefire agreement was signed. The war is replaced by a "non-peaceful" truce, which has been going on for almost a quarter of a century.

Since then, the NKR remaining a state-like entity has developed sufficiently stable forms of its political and administrative and managerial organization, socio-economic and cultural life. A ramified system of relations between the NKR and Armenia has developed, which makes it possible to solve basic problems of the social life support of the unrecognized republic; as well as bypass the difficulties that their population faced in connection with the international "non-subjectivity" of their society (for example, an opportunity to obtain Schengen visas, etc.).

So, the history of the NKR represents a road map already implemented in practice, which Eastern Donbass will largely follow (and already follows) in the course of its development. This scenario, as we see, does not presuppose the republics' inclusion of in Russia even in the long term of two or three decades. By the example of the combination "ArmeniaNKR" it is obvious that the main strategic goals and guidelines of the unrecognized community can be achieved without its full reunification with the "parent" state.

Thus, the process of state bodies' system formation in Eastern Donbass, further legitimizing of the vertical power of the republics through activation of local party life and finalizing the system of elections for leaders and deputy corps of various levels are expected to be completed in the coming years.

Taking into account the fact that the population of the self-proclaimed republics became the most injured party of the conflict in the east of Ukraine which is currently deprived of a significant part of the opportunities open to both residents of Russia and Ukraine, the only thing which remains is to hope for the gradual creation of a ramified system of informal procedures performed by means of correspondent Russian agencies and institutions, which would let at least partially compensate the inhabitants of Eastern Donbass for its illegitimate status.

\section{Ethno-demographic prospects for Donbass}

By the beginning of 2017 direct and indirect (as a result of mortality growth and fertility reduction) irrevocable losses of the population living in Donbass were about $70-90$ thousand people (about $1.5 \%$ of its population). At least $300-400$ thousand people permanently left the region (migration to Russia and other regions of Ukraine for permanent residence) with a view of this figure increase by several hundred thousand people in the coming years. It is explained by the fact that a definite part of population having left the region in the course of active military actions is still uncertain about its place of living (Сущий, 2016).

And if before the beginning of the crisis in the $D(L) P R$ there were over 4 million residents, now this number is about 3 million with an opportunity of certain growth of this figure in case of military and socio-economic stabilization.

The national structure of region's population also underwent changes. A certain ethno-cultural "separation" of local territorial communities began since the inception of the military conflict connected with extensive migration beyond the region. Ukrainiancentered (the majority being ethnical Ukrainians) residents of Donbass moved to other regions of Ukraine, Russian-centered population (with high percentage of Russians) moved to Russia.

By the time the frontier line reached stabilization and active military actions ended, the ethno-cultural disengagement of newly formed regional societies had already happened, although a detailed analysis of territorial boundaries of pro-Russian and Ukrainian Donbass discloses an obvious discrepancy of ethnical borders and the line of military confrontation. A number of Ukrainian residents remained to live on the territory of the self-proclaimed republics and a large number of Russians continued to live on territories under control of the Armed Forces of Ukraine. But the following fact is beyond dispute - a tangible majority of regional Russian population took side of militia and a big part of local Ukrainians would like Donbass not to be separated from Ukraine.

In this case, it is necessary to take into account the fact that this region was the territory with the highest share of mixed Russian-Ukrainian population (Савоскул, 2001). If there is now more than a quarter of a bi-ethnic majority of population (the offspring of Russian-Ukrainian married couples) within the rest of Ukraine, up to half of the local residents could belong to it in Donetsk and Lugansk regions. The choice of the party in the conflict by such a population was determined not only by internal 
convictions, but also by the sum of concrete life circumstances of every individual.

It can also be assumed that the socio-political and economic dynamics of the republics of Eastern Donbass will determine the further ethnic dynamics of its population to a significant extent. The most numerous part of the outflow from the Ukrainian part of the region to the territory of the DPR and LPR will be Russians (including a mixed population that ethnically identifies itself as the Russian one). And, consequently, the quantitative and fractional preponderance of Ukrainians among the population of territories belonging to Donbass controlled by Kiev will begin to grow rapidly (especially since the remaining Russian and bi-ethnic population there will be the object of an integrated, purposeful program of "title conferring").

Accordingly, the evolution of the ethnic structure of the population of the republics will be reverse in its central vector, a part of the Ukrainian-centric population of these republics leaving the territories and awaiting the return of Eastern Donbass to the control of Kiev. With the loss of this hope the territory of the DPR and the LPR can be left by minimum hundred thousand of their Ukrainian inhabitants. Moreover, socio-economic problems will contribute to it.

Thus, the consolidation of the republics as stable political and administrative and territorial entities in the medium term (by 2025-2030) may lead to a quantitative predominance of the Russian population within their borders (taking into account biethnophors with Russian ethnic self-identification). Meanwhile, until recently Ukrainians dominated quantitatively on the territory of the future republics of Eastern Donbass. According to the 2001 census, they accounted for $50-55 \%$ of local residents, Russians accounted for $40 \%$ of the population (Всеукраинская перепись населения 2001).

By 2014 these shares slightly changed, and the number of Ukrainians still exceeded the number of Russians by $30-40 \%$. But during the military confrontation about 1.0-1.5 million people rescued to Russia and other regions of Ukraine. A significant number of migrants forced to move subsequently returned to the self-proclaimed republics. And, nevertheless, many hundreds of thousands of people remain outside the borders of the republics. Dozens of thousands have already received Russian citizenship, begun to take roots in various regions of Russia maintaining the status of refugees. Ethnically, this population could generally correspond to the national structure of the entire population of Donbass (or differ somewhat in slightly higher proportion of Russians).
On the other hand, hundreds of thousands who moved to other regions of Ukraine and did not want to return to the jurisdiction of the people's republics were in the majority represented by the Ukrainians. And in the share ratio these "Ukrainian" losses of the general demographic potential of Eastern Donbass are highly likely to dominate. In other words, as early as in 2015-1016, the ratio of Russians and Ukrainians in the population of the self-proclaimed republics could be significantly "balanced", especially after a massive return of refugees to the DPR and the LPR from Russian regions.

Finally, it is necessary to take into account the obviously reversed identity dynamics of the local mixed Russian-Ukrainian population. If up to $80 \%$ of the representatives of the bi-ethnic population living on all the territories belonging to Ukraine already identified themselves as Ukrainians by 2014, this ratio was not so unbalanced within the Donbass region, in which Russia's influence remained very noticeable. However, after two decades of state independence of Ukraine about two thirds of local bi-ethnopfors could also choose a titular nationality under their national self-determination. The appearance of the $D(L) P R$ was to stop the process of bi-ethnic population bias towards Ukrainian self-identification, and the political stabilization of the republics was to inevitably include a reverse trend (there is every reason to consider it already included).

An outside observer can ironize on such "weathercock" behaviour of the local population concerning their identification. But in the context of Donbass' status of an ethnocultural limitrophe, this mimicry under the social and ethno-cultural trend that dominates the society is an inevitable behavior strategy for a significant part of local residents being far from politics and engaged in the organization of their own lives. Given that up to a half of population can belong to bi-ethnophors within the republics, the transition of even $10-15 \%$ of representatives of this group from the group of Ukrainian identification to the Russian one can make the number of the two leading national communities of Eastern Donbass quantitatively comparable.

So, the socio-political fate of Donbass will also largely determine the further ethnic evolution of its population, both in the western (Ukrainian) and the eastern ("republican") parts.

At the same time, however, it is necessary to state that any of the possible scenarios of the region's demographic dynamics in the current situation will be associated with a large-scale loss of its population, although, its demographic losses are estimated to date at hundreds of thousands of people (Сущий, 2016). But demographic problems connected with 
systemic "burdens", especially sensitive for the selfproclaimed republics, can be huge as well. These burdens are an uncertain socio-political status, the front-line situation of the largest centers (including two capitals - Donetsk and Lugansk), and the low material level of the population and serious socioeconomic problems.

These circumstances will determine the steady outflow of young people and qualified specialists outside the republics. This migration trend has been clearly recorded in the last two or three years. But in the medium term it is able to become an independent factor in the socio-economic stagnation of the republics, a catalyst for the already increased natural loss of their population and its accelerated aging.

\section{Economy of Eastern Donbass - realities and prospects}

Until early 2014 Donetsk and Lugansk regions had significant economic potential and were a part of the group of the most industrially developed regions of Ukraine. The main branches of the industrial complex of Donbass include metallurgy, chemical industry, production of coke and refined products, coal industry and machine building.

The total GRP of two regions in 2013 exceeded 29 bln. USD, what was $16.2 \%$ of the total GDP of Ukraine (Tab. 1). The largest industrial centers of Donetsk region apart from the regional capital were Mariupol,
Avdeevka, Artemovsk, Kramatorsk, Slavyansk. Metallurgical, machine-building enterprises and also serious coke-making capacities were concentrated in the region. The leading centers of industry in Lugansk region were Severodonetsk, Lisichansk, Rubezhnoye, where manufacturing of chemical products was concentrated (Донбасс: экономика и промышленность, /no data/).

Thus, the central segment of the economy of Donetsk and Lugansk regions forming GRP was heavy industry. The volume of industrial products sold in Donetsk and Lugansk regions in 2013 amounted to $27.6 \%$ of the total volume of industrial products sold in Ukraine (with a $14.5 \%$ share of Donbass in the population of the country).

Due to the activities of enterprises of these two regions almost half of the country's foreign currency earnings used to be formed, a significant part of the entire export potential of Ukraine was concentrated in Donbass. Thus, Donetsk and Lugansk regions were budget-forming for the country, having a significant impact on the economic dynamics of all Ukraine. And despite the well-known structural conservatism of the region's economic system, at the beginning of the 21 st century (until 2014) it demonstrated a sufficiently high production and trading activity, remaining attractive to foreign investment.

The Ukrainian socio-political crisis of 2014 and the war that followed had the most negative impact on the scale of industrial production in the region, both parts of the regions separated with a front line.

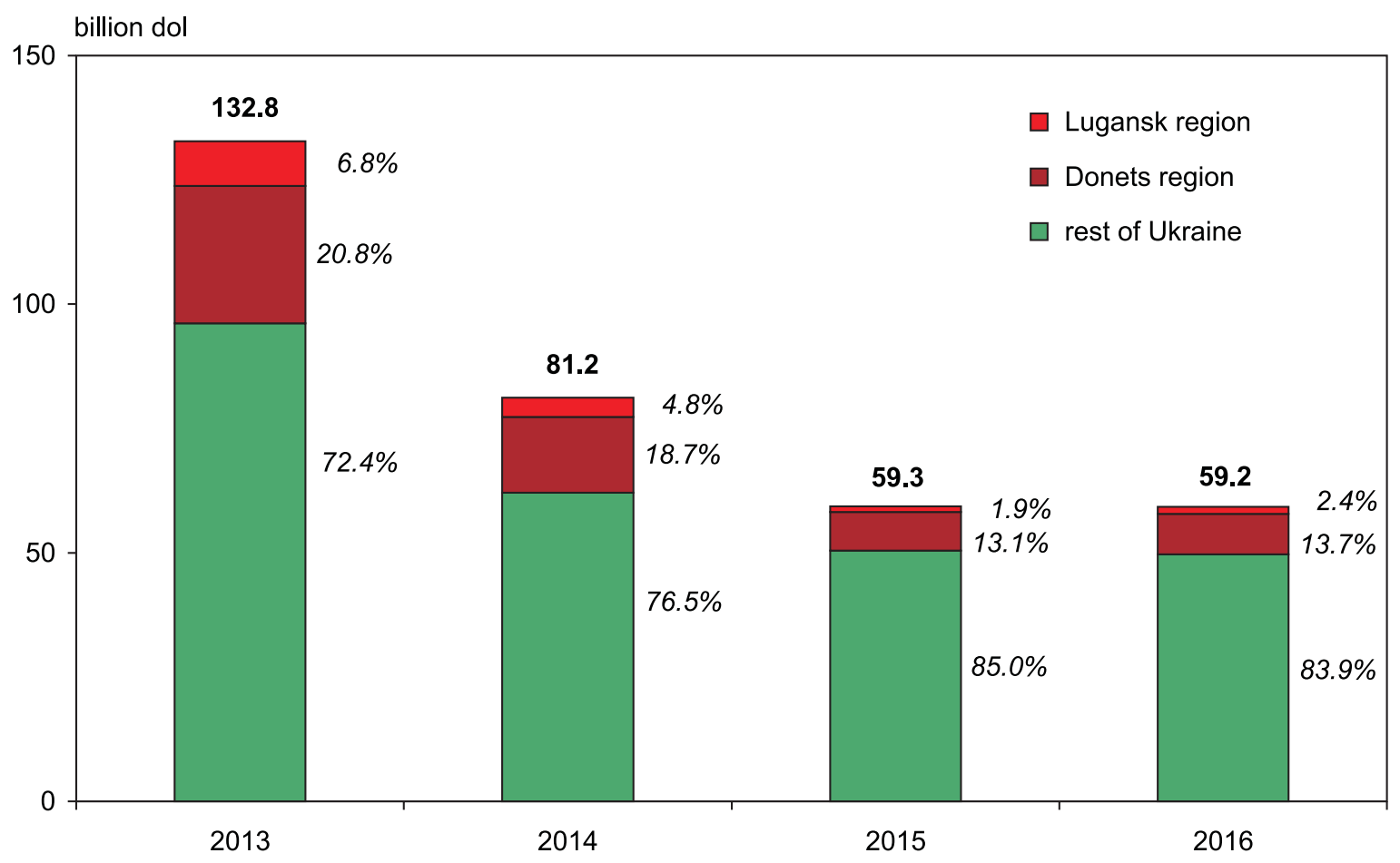

Fig. 1. Volume of sold industrial products in Ukraine, mln. USD, \%

Source: calculated by authors on the basis of: Государственная служба статистики Украины. 
Tab. 1. The share of Donetsk and Lugansk regions in GDP of Ukraine before the military conflict

\begin{tabular}{|l|c|c|c|}
\hline \multicolumn{1}{|c|}{ Regions } & GRP (bln. USD) & $\begin{array}{c}\text { Region's share } \\
\text { in the country's IPP (\%) }\end{array}$ & $\begin{array}{c}\text { Place among country's } \\
\text { regions }\end{array}$ \\
\hline Kiev, city & 33.9 & 18.51 & 1 \\
\hline Donetsk region & 22.0 & 12.02 & 3 \\
\hline Dnepropetrovsk region & 18.8 & 10.24 & 7 \\
\hline Lugansk region & 7.7 & 4.19 & 2 \\
\hline
\end{tabular}

Source: calculated by authors on the basis of: Государственная служба статистики Украины.

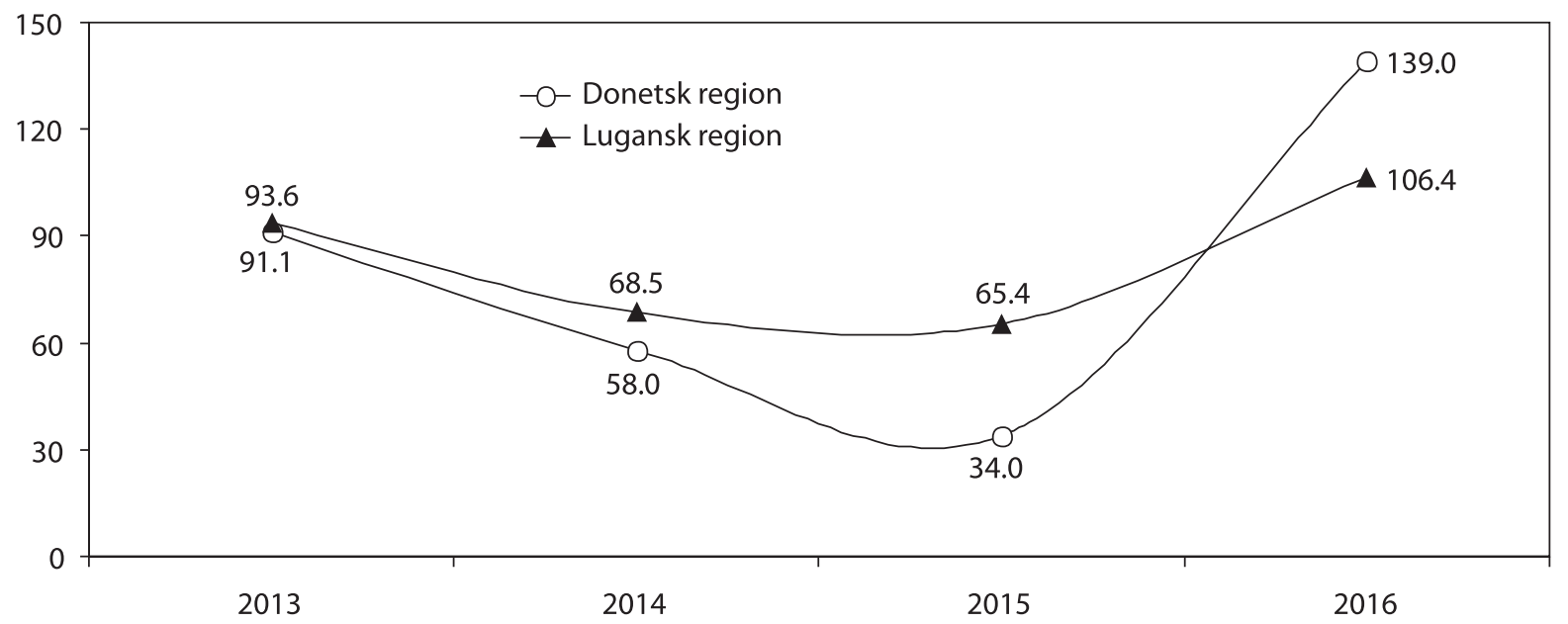

Fig. 2. Index of industrial production of Donbass (\% to the previous year)

Source: calculated by authors on the basis of: Государственная служба статистики Украины.

The volume of industrial products sold on the territory of Donbass since the beginning of the crisis became 3.5 times smaller in dollar terms. If in 2013 sold industrial products amounted to $34.2 \mathrm{bln}$. USD in two regions, then after three years (2016) they amounted only to 9.6 bln. USD (Fig. 1).

The decrease in general price indicators is confirmed by a general fall in the index of industrial production (quantitative indicators). Even the growth of indices of industrial production in 2016 (Donetsk region - 106.4\%, Lugansk region - 139\%) (Fig. 2) is a relatively positive result, because as seen from the graphs there was significantly less rapid decline in the production scale fixed during the period of 2014-2015. In its turn, the cumulative (the base year is 2012) index of industrial production as of the end of 2016 decreased to the following indicators: Donetsk region $-44.6 \%$ (a fall of $55.4 \%$ ), Lugansk region $-24.9 \%$ (a decline of $75.1 \%$ ).

But the real scale of the decline in economic activity in 2014-2016 can be even greater, since there is no detailed industrial production statistics for the $\mathrm{D}(\mathrm{L}) P R$, and the data presented on the official websites of the state statistical services of Ukraine are corrected "retroactively", which can seriously affect their validity. However, despite the lack of accurate information, it is obvious that at present the powerful economic and commercial potential of the region is being implemented to the smallest extent due to the hostilities and the absolutely uncertain legal status of Eastern Donbass.

At the same time, despite the deep structural crisis both parts of the previously unified regional production complex faced, the problems the economy of the self-proclaimed republics has are more serious, as the industrial enterprises of the Ukrainian part of Donbass have survived in the economic system of their country.

The total number of enterprises on the territories of the Donetsk and Lugansk People's Republics, according to approximate calculations, is about 23 thousand, about 60 of them being large enterprises of mining and metallurgical and machine-building complexes; about a thousand of them are production associations of medium-sized businesses.

65 thousand of people work at the enterprises under external management, and taking into account the structures cooperating with them, the number of workers in this economic segment of Eastern Donbass reaches 200 thousand:

- "Metinvest" (OJSC "Khartsyzsk Tube Plant", CJSC "Enakievo Metallurgical Plant", Makeyevka Branch of OJSC "Enakievo Steel Plant", CJSC "Komsomolskoye Rudoupravlenie"); 
- United Minerals Group (CJSC "Dokuchaevsk flux and dolomite plant");

- DTEK (OJSC "DTEK Rovenkyantratsyt", "DTEK Sverdlovantratsyt", JSC "DTEK Mine "Komsomolets Donbassa”, LLC "DTEK Service", DTEK"Donetskoblenergo");

- ISD (OJSC "Alchevskkoks", OJSC "Alchevsk metallurgical plant", CJSC "Ecoenergy"), "Donetsksteel" (CJSC "Donetsksteel - Metallurgical plant Donetsk"; CJSC "Makeevcoke", OJSC "Yasinovsky Coke-chemical Plant");

- OSTCHEM (OJSC "Concern Stirol").

Donbass accounted for 56-64 million (about 75$78 \%$ of all coal mining) out of $74-83 \mathrm{mln}$. tons of coal produced in Ukraine in 2001-2013. At the same time, $25-30 \mathrm{mln}$. tons (34-36\%) were mined directly on the territories of the modern $\mathrm{D}(\mathrm{L}) \mathrm{PR}$. But significant positions in the national economy were also occupied by metallurgy, as well as machine building and chemical industry of Donbass.

However, recognizing the powerful industrial potential of the $D(L) P R$, it is necessary to take into account the fundamental fragmentation of its available sectoral structure (Fig. 3), due to the fact that the single industrial complex that was formed in the region for a century has now been divided by the front line. Six of the ten leading industrial hubs in Donbass are located within the $\mathrm{D}(\mathrm{L}) \mathrm{PR}$, four - on the territories controlled by Kiev. The majority of production chains that connected not only entire industries and segments of the regional economy, but also specific enterprises were disrupted. Similar gaps have passed through the Donbass transport system and its central life support systems (electricity, gas and water supply).

People's republics do not have their own port facilities. But there is no full-fledged alternative for Mariupol as a maritime transshipment centre of manufactured products. The capacities of Taganrog are inferior to Mariupol (1.3-1.5 mln. of cargo turnover versus $14-15 \mathrm{mln}$. tons) and are fully loaded with products of Russian manufacturers. It is a complete utopia to build a large trading port in Novoazovsk from scratch with the modern financial and economic capabilities of the self-proclaimed republics. It also concerns an attempt to "retake" Mariupol from Ukraine.

But the analysis of the socio-economic system of the self-proclaimed republics makes it possible to single out a number of other serious structural limitations on their dynamic economic development:

- a reduction of electricity required for economic and public needs (Starobeshevskaya TPS, Luganskaya TPS, Zuevskaya TPS operate on anthracite coals extracted in the $\mathrm{D}(\mathrm{L}) \mathrm{PR}$ (the cost of production is high), their capacity being about 3000 $\mathrm{MWt}$, and cannot fully meet the needs of metallurgical, chemical and machine-building enterprises (deficit is about $500-800 \mathrm{MWt}$ ));

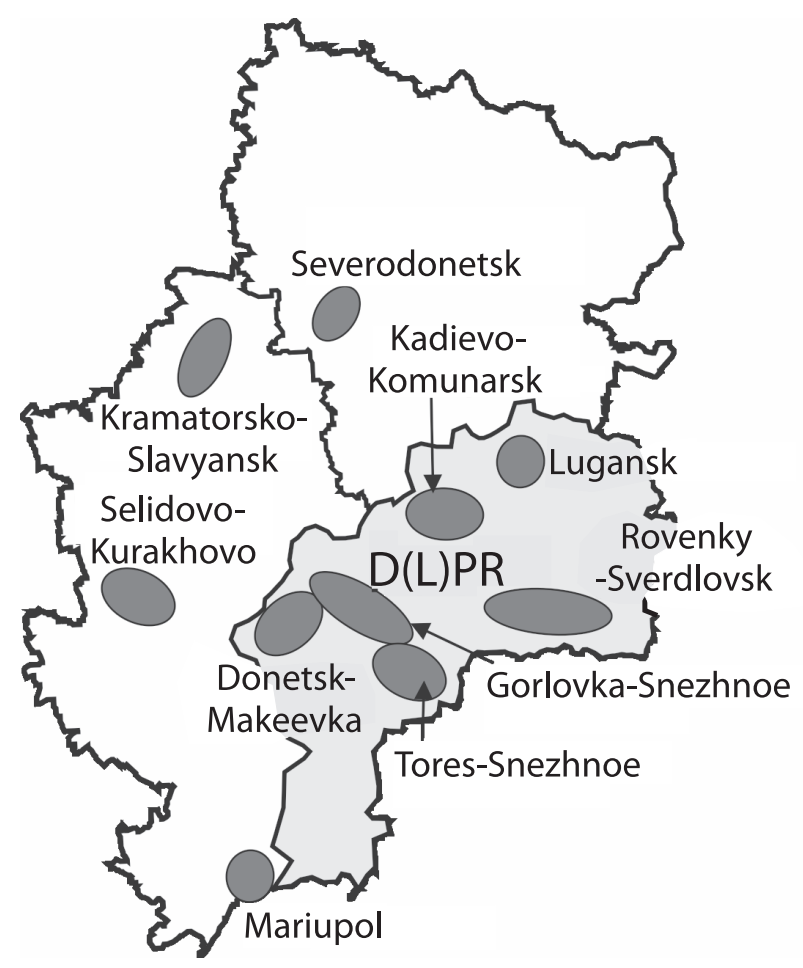

Fig. 3. Leading industrial hubs of the early twenty-first century industrial complex of Donbass

Source: compiled by authors according to the materials: Донбасс. Экономика_и_промышленность /no data/. 
- a lack of the required amount of coking coal (the coal types produced on the territory of the $D(L)$ PR do not belong to coking coal (this is energy anthracite) and accordingly this leads to the inability to produce coke, one of the key resources in the production of pig iron and steel (a deficit of about 3.0-3.5 mln. tons). It is a serious blow to the entire steel industry of the $D(L) P R)$;

- a lack of a sales market for metallurgical enterprises of the $D(L) P R$ (the lack of international recognition of the republics makes it absolutely impossible to export metal products (pipes, sheet metal, square billets) to traditional markets (Poland, Italy, the USA, some countries of the Persian Gulf));

- a lack of a sales market for machine-building enterprises of the $D(L) P R$ (a significant part of enterprises of the D(L)PR (JSC "Donetskgormash", Gorlovka Machine-Building Plant, etc.) was "imprisoned" for export of mining equipment to Kazakhstan and Russia (the EAEC). In addition to these countries, in the framework of vertically integrated companies (R. Akhmetov, V. Novinsky, D. Firtash, I. Kolomoisky), this equipment was delivered to Dnepropetrovsk, Zaporozhian and Odessa regions);

- potential threats to food security of the $D(L) P R$ (based on the economy structure of the $D(L) P R$ as an industrial economic system, agriculture occupies an insignificant place in the gross regional product, and consequently, the food blockade of the republics implemented by Ukraine since 2017 determines their extremely high dependence on the supply of agricultural products from the Russian Federation).

Analysis of the socio-economic dynamics of Eastern Donbass in 2014-2017 allows us to conclude that initially the line of scenarios for the strategic development of the economy of the self-proclaimed republics included the widest range of opportunities which could be reduced to the maximum of three options, each of which included a number of sub-variants:

- preservation of Eastern Donbass in the financial and economic space of Ukraine;

- transformation of the $D(L) P R$ into the territory of intersection and dense mutuality of the Ukrainian and Russian financial and economic systems;

- transition of the republics to the life cycles of the Russian economy.

However, by the beginning of the Minsk negotiations (autumn 2014), the obvious refusal of Moscow to repeat the Crimean scenario with respect to Eastern Donbass excluded the possibility of the third designated scenario - the transition of the republics to the Russian Federation as its regions with their subsequent "legal" and complex integration in the Russian economy.

And since the beginning of 2017, since the establishment of a comprehensive blockade of the republics by nationalists, in fact, supported by the Ukrainian political leadership, the first option finally left in a history - the possibility of any tangible preservation of Eastern Donbass in the financial and economic space of Ukraine.

Moreover, if the complete utopism of this scenario in its politically legalized version became clear already by the spring-summer 2015, then the shadow version (the formation of a significant number of "gray" trade schemes between the republics and Ukraine) was widely present in the economic life of the region until the end of 2016.

Suffice it to say that about $9 \mathrm{mln}$. tons out of 12 $\mathrm{mln}$. tons of coal extracted in the DPR this year were transferred to Ukrainian consumers and only one million was sold to Russia. (Горняки ДНР..., 2017; Украина ежегодно покупает..., 2016).

The obvious orientation of local producers to traditional Ukrainian markets and the scale of this grassroots trade itself, taking into account its mutually beneficial nature, allowed us to hope for the longterm preservation of this palliative variant of the earlier existing system of production cooperation.

But the beginning of 2017 clearly demonstrated that implementing the strategy of an integrated (financial, socio-economic, food) blockade of the republics, Kiev is ready to abandon any forms of mutually beneficial economic interaction. Not to let the $\mathrm{D}(\mathrm{L}) \mathrm{PR}$ take place as an economically successful, socially prosperous society is one of the priorities of the modern Ukrainian government, which it will realize consistently, rejecting any of its own pragmatic interests, if necessary (Матишов, 2016).

\section{Possible scenarios of socio-economic development}

Thus, at present the only realistic scenario of socioeconomic development of the republics remains their progressive "shadow" integration into the life cycles of the Russian economy. However, a wide range of sub-variants differing in the level of systematics and the scale of support for the production segment and the social sphere of the $D(L) P R$ from Moscow has emerged within this basic scenario in its turn.

This set of more or less realistic trajectories of economic development of the republics fits two extreme 
variants which can be conditionally designated as positive (optimistic) and negative (pessimistic).

The positive scenario assumes a sharp (multiple) increase in the financial support for the social sphere and economy of the republics from the Russian budget, a significant acceleration and expansion of administrative and managerial, legal, transport and logistics, investment activities to form a single territorial and economic complex linking the economy and the basic systems of social life support of Eastern Donbass with Rostov region (the only Russian region with which the republics have a common land border) and broader - with all the Russian socio-economic system.

Of course, this complex work can significantly complicate the fact that actual integration should remain not formal, taking into account the indefinite socio-political status of the republics. But in case there is a clearly defined political will, this problem can be completely solved, as well as the issues of legalization through the Russian commodity flows of industrial products of the republics. Remember that their volume even in coal mining does not exceed $3-4 \%$ of the total scale of Russian production, and it is one tenth or hundredth of a percent in other industry segments.

Thus, the purposeful work of Moscow is able to significantly accelerate the economic incorporation of Eastern Donbass, considerably increasing the financial self-sufficiency of the pro-Russian region in a matter of years. Moreover, given the already existing infrastructure, the centuries-old industrial traditions of the region and its population, the integrated industrial complex of Rostov region and the $D(L)$ PR could become one of the leading in the Russian heavy industry in the medium term (by 2030-2035).

The negative scenario of development will be associated with the persistence of the current socioeconomic situation for a long period of time, which, in the context of total disruption of trade and economic ties between Eastern Donbass and Ukraine, and limited, slowly growing trade with Russia, will evolve into systemic stagnation of the republics, large-scale degradation of their infrastructure and human capacity. It will probably happen, especially if the financial support from the federal centre will remain as minimalistic and focused not on the development of Eastern Donbass, but solely on subsidizing the basic social needs of its population (which is obviously necessary but absolutely inadequate for the withdrawal of the republics to the path of sustainable growth). In the demographic aspect, the negative scenario will be associated with a sustained and accelerated decline in population, related both to its natural decline and the growing outflow from the region.

It is obvious that the two scenarios set the general direction of the oppotunities of socio-economic dynamics of the $\mathrm{D}(\mathrm{L}) \mathrm{PR}$, their actual development being likely to represent a certain intermediate variant.

However, the economic dynamics of the republics in 2017 points to an increased danger of the implementation of the scenario approximating the pessimistic forecast. At least six months after the beginning of Ukraine's trade blockade of the republics, Russia has practically not increased the procurement of Donbass coal, despite the fact that it is an important (if not a central) budget item replenishing the republican budgets. Many other facts of the modern economic life of the region testify to the domination of extensive forms of interaction between Russia and Eastern Donbass.

The reasons for such sluggishness can be multiple and the time for broad conclusions has not yet come. But a number of factors directly or indirectly work to preserve the current situation. One of the factors is obvious reluctance of Moscow to proceed with the implementation of a new large-scale integration project.

But you can find other reasons. As you know, the task to financially "outweigh" Eastern Donbass against Russia was one of Kiev's goals. At the same time, a certain part of the domestic expert community was also convinced that in this case the self-proclaimed republics would become a black hole for the Russian budget, having a very negative impact on the socio-economic development of Russia, already burdened by international sanctions, the economic crisis and the decline in the living standards of the population (Украинский кризис..., 2015; Матишов, 2016).

The amount of current financial support for the $\mathrm{D}(\mathrm{L}) \mathrm{PR}$ from Russia refers to closed statistics. But this does not impede the identification of the most general of its quantitative order. The population of Eastern Donbass is about $2 \%$ of the number of Russians. And the general price level in the republics is 2.0-2.5 times lower than the average for the Russian Federation. Thus, subsidies from the federal budget for the social needs of the population of the $D(L) P R$ are likely to be less than $1 \%$ of the total amount of these expenditures across Russia and are comparable to the scale of "supporting" transfers in one rather small region of the country, what is absolutely uncritical for the federal budget.

And this circumstance, perhaps, is the main danger for the $D(L) P R$, since it can cause Moscow's desire to maintain the existing system of interactions with Eastern Donbass as long as possible and which does 
not require the Russian leadership to do extensive and focused work, to move from a "reactive" policy to the implementation of a large-scale long-term project on the inclusion of the self-proclaimed republics in the socio-economic system of the Russian Federation. Moreover, such a project will require not only really serious investments/ subsidies to Eastern Donbass (at least a few bln. USD), but also quality management support. And modern Russia has big problems with these two resources.

Therefore, despite obvious strategic benefits of complex integration of the $D(L) P R$ into the life cycles of Russia, the bureaucratic tactics of minimizing financial and economic costs and managerial efforts in this direction can prevail in the policy of the Russian leadership, which can turn out to be more serious (including directly financial) losses in the more distant future.

But it should be repeated that the situation in the social and economic sphere remains open by mid-2017, not allowing broad generalizations to be made. And the only obvious fact is that the economy of the $D(L) P R$ practically in any scenario of its further evolution will maintain a certain continuity with its historically established structure in which the sectors connected with the extraction and processing of coal, as well as metallurgy, various types of engineering and chemistry, that is a complex of industrial specializations that distinguished the economy of Donbass throughout the region's existence, play the important role. However, the relationship between them can significantly change depending on the specific forms of adaptation of the region's economy to the new conditions of its functioning.

And in general, in the next few years a serious spatial transformation of the entire infrastructure complex of the $D(L) P R$, including a network of transport communications and the basic systems of social life support, is expected. The transformation is caused by a radical turn of trade and economic ties of the region to Russia and the need to move the central infrastructural hubs of the republics away from the front line.

In addition, there are serious reasons to believe that main features of the future socio-economic development model of Eastern Donbass will be determined in the coming years - by the beginning of the 2020s, maximum by the middle of this decade.

So in the three years of their existence self-proclaimed republics of Donbass have followed a considerable path of development. Their establishment as independent states/state-like entities in mid-2017 was not finally completed. But they managed to make the most significant part of their way.

The next few years will represent an extremely complex and responsible period in all the main spheres of the life of Eastern Donbass capable to definitely define and formalize new forms of sociopolitical, managerial, financial and economic, sociocultural life of this pro-Russian society.

\section{Acknowledgements}

The paper is written in the laboratory of social and economic researches of the FIS Southern Scientific Center of the Russian Academy of Sciences in the framework of research work 00-18-20, 0256-20180014, № AAAA - A 16-116012610047-9"Problems of demographic and socio-economic development of the Southern macro-region".

\section{References}

Всеукраинская перепись населения 2001, Державний комітет статистики України, http://2001.ukrcensus.gov. ua/ [25.11.2017].

Горняки ДНР в 2016 году добыли более 12 млн тонн угля, 2017, http://rusvesna.su/news/1483976642 09.01.2017 [27.07.2017].

Государственная служба статистики Украины, http:// www.ukrstat.gov.ua/. [23.07.2017].

Донбасс. экономика и промышленность, Википедия, https://ru.wikipedia.org/wiki/Донбасс\#Экономика_и_ промышленность [29.07.2017].

Корнелл С., 2000, Конфликт в Нагорном Карабахе: динамика и перспективы решения, http://old.sakharovcenter.ru/publications/azrus/az_015.htm [25.11.2017].

Матишов Г.Г., 2016, Опасные тенденции и риски на южном фланге России, Ростов-на-Дону, ЮНЦ РАН, Ростов-наДону.

Пихорович В.Д., 2015, Украина между Западом и Востоком. Война на Донбассе, URSS, Москва.

Проблемы полиэтничного макрорегиона в условиях дестабилизации Каспийско-Черноморского зарубежья, 2015, ЮНЦ РАН, Ростов-на-Дону.

Рожин Б., 2014, Контуры Большого Приднестровья, LIVEJOURNAL, http://colonelcassad.livejournal.com/1814701. html [16.07.2017].

Савоскул С.С., 2001, Русские нового зарубежья: выбор судьбы, Наука, Москва.

Сущий С.Я., 2015, Украина - Россия - Мир: до и после 2014 года (некоторые аспекты взаимодействия, Ленанд, Москва.

Сущий С.Я., 2016, Военный конфликт на востоке Украины: демографические потери и сдвиги в национальной структуре населения Донбасса, Наука Юга России (Вестник ЮНЦ), 2, 82-91. 
Украчна ежегодно покуnает до 9 млн. тонн угля с оккупированных территорий, 2016, СТPAHA.UA, https://strana.ua/news/45571 [02.08.2017].

Украинский кризис: истоки, тенденции и уроки, 2015, ЮНЦ РАН, Ростов-на-Дону. 